\title{
Z nowych badań nad dialogiem Sokratejskim
}

Livio Rossetti, Le dialogue socratique, Éditions Les Belles Lettres, Paris 2011, ss. 296.

\section{SEAWOMIR TORBUS / Wroctaw /}

Książka stanowi zbiór tłumaczonych na język francuski ośmiu artykułów profesora Livio Rossettiego, które poświęcone są osobie Sokratesa i dialogom sokratejskim. Teksty te ukazały się w czasopismach oraz pracach zbiorowych na przestrzeni lat 1998-2010 - na stronie 13 znajdujemy dokładne odniesienia bibliograficzne. Po spisie treści (s. 15) następuje przedmowa autorstwa François Roustanga (s. 17-21), w której zwraca on uwagę na najważniejsze wątki poruszane przez Rossettiego w jego tekstach - naturę dialogów sokratejskich jako gatunku literackiego, jego koncepcję „makro-retoryki” oraz pewne propozycje rozwiązania kwestii „historycznego Sokratesa”. Artykuły Rossettiego zaprezentowane zostały na stronach 23-277. Podane są one nie w porządku chronologicznym, ale rzeczowym, pozwalającym na systematyczne zapoznawanie się z kolejnymi, wynikającymi z siebie, jeden po drugim, elementami koncepcji uczonego. Książka zaopatrzona jest w obszerną bibliografię przedmiotu (s. 279-288) oraz indeks nazwisk (s. 289-292).

W pierwszym tekście - „Le dialogue socratique in statu nascendi” (s. 23-53), Rossetti zwraca uwagę na, często niezauważany przez specjalistów, fenomen bujnego rozkwitu 
twórczości pisarskiej w zakresie tzw. logoi Sokratikoi, których liczbę szacuje wstępnie na około 300 utworów, napisanych w okresie pierwszych 25 lat IV w. przed Chr. Fenomen ten tłumaczy autor potrzebą przeciwdziałania przez uczniów Sokratesa możliwości utrwalenia się w społeczeństwie negatywnego obrazu ich mistrza, a co za tym idzie, całej szkoły filozoficznej. Istotnym bodźcem $\mathrm{w}$ tym kierunku była z pewnością publikacja antysokratejskiego pamfletu Polikratesa - nie byłaby to jednak bezpośrednia, ale raczej, jak określa to Rossetti, towarzysząca przyczyna (une cause concomitante) zaistnienia tak dużej ilości szczególnego rodzaju tekstów literackich. Rozważania Rossettiego prowadzą do wniosku, że w przypadku rozkwitu twórczości autorów logoi Sokratikoi nie mamy do czynienia z powstaniem nowego gatunku literackiego, ale raczej ze świadomym posługiwaniem się przez twórców pewnym schematem już wcześniej wykorzystywanym w kręgach sokratejskich.

Kolejny artykuł Rossettiego - „L' Euthydème de Xénophon” (s. 55-99) - poświęcony jest, znajdującemu się w 2 rozdziale IV księgi Wspomnień o Sokratesie Ksenofonta, dialogowi Sokratesa z Eutydemem. Dialog ten, określony tu mianem: Eutydem, zdaniem Rossettiego stanowi jeden z najwybitniejszych tekstów Ksenofonta - na miarę największych arcydzieł samego Platona. Autor uważa, że tekst ten, wbrew opinii niektórych interpretatorów, nie przekazuje właściwie żadnych informacji na temat poglądów Sokratesa ani też nie ma na celu powiedzenia czegoś nowego na temat sokratejskiej metody nauczania, choć naświetla pewne aspekty osobowości filozofa - jego skłonność do posługiwania się kontrprzykładem, a także ironią, jak również, postrzegane jako ekscentryczne, umiłowanie aporii, o którym czytamy także w Teajtecie (149 a 8-9). Właściwy cel tego dialogu określa Rossetti jako metakognitywny i zwraca uwagę, że widziany z tej perspektywy wpisuje się on w tradycję wielu tekstów sofistycznych, jak i logoi Sokratikoi, które zresztą mogły stanowić dla Ksenofonta inspirację. Mogłoby to w jakiś sposób tłumaczyć skomplikowaną strukturę tego tekstu i jego wyjątkowość w ramach Wspomnień o Sokratesie. Jako tekst metakognitywny Eutydem nie służyłby komunikowaniu jakichś prawd czy twierdzeń, ale miałby raczej opisywać skomplikowaną rzeczywistość, która wymaga pełniejszego zrozumienia. W tym sensie Eutydem nie tyle komunikuje czytelnikowi jakieś twierdzenia, co stanowi zachętę do podjęcia refleksji nad pułapkami, które mogą kryć się za pewnymi tezami o charakterze ogólnym. W gąszczu problemów, kontrprzykładów oraz aporii podnoszonych przez Sokratesa, czytelnik gubi się razem z Eutydemem po to, by w końcu zrozumieć, że w niektórych kwestiach, nawet tych, które wydają się być jasne i oczywiste, należy być bardzo ostrożnym w wyciąganiu ostatecznych wniosków. Rossetti jest zdania, że postrzeganie Eutydema w perspektywie metakognitywnej pozwala lepiej zrozumieć sens podnoszenia w dialogu tak wielu szczegółów oraz decyzje autora dotyczące struktury tekstu.

Krótki artykuł zatytułowany: „Savoir imiter c'est connaître: le cas de Mémorables III 8" (s. 101-119) poświęcony jest problemowi wiarygodności Ksenofonta jako świadka przekazującego informacje na temat „historycznego Sokratesa”. Przez długie lata wśród badaczy rozpowszechniona była tendencja do kwestionowania wartości historycznej relacji Ksenofonta w tym zakresie, jednak w latach siedemdziesiątych XX wieku 
uczeni zaczęli dystansować się od traktowania tekstów Ksenofonta jako jedynie wtórnych i pomocniczych źródeł wiedzy o Sokratesie. Przeprowadzona przez Rossettiego krótka analiza 8 rozdziału IV księgi Wspomnień o Sokratesie wpisuje się właśnie w tę drugą tendencję. W opinii autora mamy tu do czynienia z bardzo wiarygodnym i klarownym świadectwem dotyczącym typowo sokratejskiej metody dyskusji, która polega na krytykowaniu idei adwersarza poprzez wykazywanie sprzeczności w jego rozumowaniu bądź postępowaniu (elenchos). Ksenofont, prezentując czytelnikowi prowadzony w tej konwencji dialog między Sokratesem a Arystypem, pokazuje, że doskonale zna reguły elenktycznej dyskusji i jest w stanie ją w mistrzowski sposób imitować. Odmalowując jednocześnie obiektywny portret Arystypa jako zdolnego naśladowcy Sokratesa, wznosi się Ksenofont na szczyty ars imitandi i wpisuje się zarazem w tradycję logoi Sokratikoi, które przedstawiają jakąś wybraną postać jako naśladowcę zwyczajów Sokratesa. Z tej perspektywy wartość źródłowa relacji Ksenofonta jawi nam się w zupełnie innym świetle niż życzyłby sobie tego choćby tak bardzo lekceważący go Schleiermacher.

W tekście zatytułowanym: „L'Eutyphron comme événement communicationnel” (s. 121-194) zastanawia się Rossetti nas specyfiką platońskiego Eutyfrona. Warto zauważyć, że autor stara się analizowany tekst osadzić bardzo mocno w jego kontekście historycznym, podkreślając jego zanurzenie w tradycji logoi Sokratikoi, między innymi, co niezwykle interesujące, poprzez oralny wymiar tekstu - przeznaczonego do głośnego odczytywania, czy wręcz teatralnego odgrywania go przed audytorium. Eutyfron, według Rossettiego, jest dialogiem, który został skomponowany w czasie, kiedy gatunek logoi Sokratikoi zaczyna święcić triumfy i doskonale wpisuje się w nurt dyskusji na temat postaci Sokratesa, przekazując zarazem poglądy samego Platona. Charakterystyczna sytuacja komunikacyjna odmalowana w dialogu wynikać może z faktu, że należałoby zaliczyć go do kategorii dialogów aporetycznych. Owa aporetyczność wpływa na dobór przez autora odpowiednich strategii komunikacyjnych, na przykład wprowadzenia dyskusji elenktycznych. Rossetti zwraca także uwagę na ujawniający się w Eutyfronie sceptycyzm wobec tradycyjnej religii greckiej, który, w kontekście skazania Sokratesa na śmierć między innymi pod zarzutem bezbożności, jest nieco zaskakujący. Proponowane w omawianym artykule wyjaśnienie tego fenomenu idzie w kierunku postawienia tezy mówiącej, że Platon napisał swój tekst w momencie, kiedy batalia o dobrą pamięć o Sokratesie została już wygrana i w związku z tym filozof może sobie pozwolić na bardziej swobodne posługiwanie się postacią swego mistrza do wypowiadania swoich własnych poglądów, już bez tworzenia atmosfery skandalu.

W stosunkowo niedługim tekście pod tytułem: „Le ridicule comme arme entre les mains de Socrate et de ses élèves” (s. 195-213) Rossetti prowadzi rozważania nad rolą, jaką w strategii Sokratesa (a zarazem i Platona) pełni ironia i ośmieszanie przeciwnika. Zauważa, że w rękach Sokratesa narzędzia te stanowią bardzo skuteczną i groźną broń, której filozof nie waha się używać przeciwko bardzo ważnym osobom, a nawet w perspektywie możliwego wyroku śmierci. Taka strategia prowokacji, w opinii Rossettiego, ma w ostatecznym rozrachunku na celu doprowadzenie interlokutora do przemiany jego myślenia (metanoia). Atak Sokratesa ma doprowadzić do swoistego kryzysu 
przekonań, który w końcu jest jednak zbawienny i przynosi ów efekt przemiany. Kryzys ten jest, co ciekawe, w odróżnieniu od kryzysów przeżywanych przez postacie kreowane przez posługującego się podobną strategią Arystofanesa, jest zawsze poważny, wręcz dramatyczny. Rossetti w konkluzji zwraca uwagę na fakt, że prestiż Sokratesa i jego uczniów nie byłby ten sam bez pomocy tej broni, którą była ironia i prowokacyjne ośmieszanie przeciwnika.

W artykule zatytułowanym: „La rhétorique de Socrate” (s. 215-244) Rossetti bardzo słusznie zwraca uwagę na zastanawiający brak zainteresowania wielu specjalistów kwestią analizy retorycznych strategii Sokratesa. Rzeczywiście można odnieść wrażenie jakby łączenie Sokratesa z retoryką było często postrzegane przez badaczy jako wręcz niestosowne w kontekście jego krytycznych wypowiedzi na temat sofistycznej erystyki. Analizując niektóre aspekty sokratejskiej retoryki Rossetti zwraca uwagę na dwa kluczowe zagadnienia - „retorykę antyretoryczną” (rhétorique de l'anti-rhétorique) oraz zjawisko, jakie nazywa makroretoryką. Autor w bardzo przenikliwy sposób analizuje strategie retoryczne używane przez Sokratesa, jak również porównuje używane przez niego środki z retoryczną praktyką Gorgiasza. W konkluzji pada mocne, ale niewątpliwe słuszne, stwierdzenie, że lekceważenie badań nad sokratejską retoryką zdecydowanie uniemożliwia zrozumienie przesłania filozofa.

Zbiór artykułów Rossettiego kończą dwa krótkie teksty: „Le côté inauthentique du dialoguer platonicien” (s. 245-263) oraz „Les socratiques «premiers philosophes» et Socrate «premier philosophe» (s. 265-277). W pierwszym z nich autor porusza wiele istotnych dla czytelnika kwestii związanych z platońską kompozycją partii dialogowych, które tworzą swoistą atmosferę jego utworów. Przy okazji odnosi się do założeń kilku ważnych współczesnych perspektyw i szkół egzegetycznych. Rossetti jest zdania, że autentyczną doktrynę Platona należy niejako „wydestylować” z jego tekstów, między innymi koncentrując się na funkcji pełnionej przez różne elementy otoczki, w której ta doktryna jest czytelnikowi prezentowana. Ostatni artykuł Rossettiego porusza kwestię narodzin greckiej filozofii i zwraca uwagę na zbyt daleko idące ustalenia badaczy, którzy często w nie do końca uprawniony sposób odmawiają myślicielom działającym przed Sokratesem statusu prawdziwych filozofów.

Podsumowując ten krótki przegląd treści omawianego tomu należy stwierdzić, że ze względu na wagę poruszanych przez Rossettiego problemów, wszechstronność autora, jak również oryginalność i trafność proponowanych przez niego rozwiązań, książka ta jest w najwyższym stopniu godna polecenia. 